\title{
仮想の温かさに触れ, 現実のぬくもりを求め
}

一仮想現実環境における身体感覚が所属欲求の喚起に及ぼす影響—

藤 桂 1 - 永井 聖剛 2

( 1 筑波大学人間系・ 2 立命館大学総合心理学部)

キーワード : 仮想現実, 所属欲求, 身体感覚

Perceiving virtual warmth, seeking real affection: The effects of somatic sensation produced in virtual reality environment on need for belonging

Kei Fuji ${ }^{1}$ and Masayoshi Nagai ${ }^{2}$

( ${ }^{1}$ University of Tsukuba, Faculty of Human Sciences, ${ }^{2}$ Ritsumeikan University, College of Comprehensive Psychology)

Key Words: Virtual Reality, Need for belonging, Somatic sensation

\section{問題と目的}

近年の仮想現実環境に関する技術は，まるで現実そのも のかと見紛うほどのクオリティで, 我々の眼前に新たな世 界を生出す水準にまで達している。それに加え, ヘッド マウントディスプレイなどの機器も登場し, 従来よりもさ らにリアリティをもって没入することが可能となった。

また,こうした特徴を持つ仮想現実環境を扱った先行研 究からは, ラバーハンドイリュージョンが生じることを示 す知見 (Lenggenhagaer, Tadi, Metzinger, \& Blanke, 2007)や，仮想的なキャラクター同士による相互作用であ っても, 実際の身体に痛覚反応をもたらすことを示した知 見 (Slater, Spanlang, Sanchez-Vives, \& Blanke, 2010) が示されている。すなわち, 仮想現実環境においても, 現 実さながらに, 実際の身体にも一定の身体感覚が発生する ことが示唆されてきた。

ここで近年, 身体感覚や動作が, 人間の認知・思考と密 接に結びついていることを示す知見も提出されている (例 えば, 永井・山田・河原, 2013)。特に Fay \& Maner(2012) では, “温かい”という身体感覚の発生が, 他者との結び つきや集団への所属を求める所属欲求の向上に結び付く ことが示されている。

これらの各分野の研究知見を総合すると, 仮想現実環境 上で示される刺激であっても, 一定の身体感覚が生じると ともに, それが認知・思考にも影響を及ぼすという可能性 は十分に予測できる。本研究では “温かさ” を題材に, 仮 想現実環境における刺激提示によって身体感覚の発生を 促すとともに, そのようにして生じた身体感覚が所属欲求 の向上をもたらすかについて検討することとした。

\section{方 法}

実験参加者 男子大学生 32 名(平均 20.9 歳, $S D=3.28$ )。 実験器具 ヘッドマウントディスプレイ (HMD) として, Oculus Rift DK1 を用いた。また, 仮想空間の提示に関し ては, The Elder Scrolls V : Skyrim を題材とした。

実験手続き （1）HMD を装着し，ゲーム画面が視界に提示さ れた後で, 非接触式赤外線体温計を用いて, 両方の手のひらの 温度の測定を行った（ベースラインの測定）。（2）続いて Slater et al.(2010)の手順を参考に, 仮想現実環境への没入感を高 めるよう, 動作および視点の同期を体験させた。（3）その後, 仮 想現実環境上で，温かさを喚起する刺激として “たき火”を参加 謝辞: 本研究の実施に際して, 平成 26 年度筑波大学心理学類卒業生谷
者の直前（近距離提示群 : 16 名）もしくは数メートル先に（遠 距離提示群 : 16 名）提示した。かつ, その前後において，手の ひらの温度を測定した。（4）HMD を外し，質問紙一の回答 を求めた。質問紙上では, 所属欲求 (小林他, 2006 より 10 項目 5 件法）について尋ねた。

\section{結 果}

仮想現実空間での刺激提示が温度感覚に及ぼす影響 手のひら の温度が, ベースラインからどの程度変化したかを算出し，これ を従属変数として, 提示条件を参加者間要因, たき火提示前後を 参加者内要因とする 2 要因混合計画分散分析を行った結果

(Figure1)，交互作用が有意であった $(F(1,30)=4.83, p<.05$, $\left.\eta \mathrm{p}^{2}=.14\right)$ 。そこで単純主効果検定を行った結果, 近距離提示群 において提示前と提示後の間で有意差が示され $(p<.01)$, また, 遠距離提示群でも提示前と提示後の間で有意傾向の 差が示された $(p<.10)$ 。加えて, 提示後において, 近距離 提示群と遠距離提示群の間で有意差が示された $(p<.05)$ 。

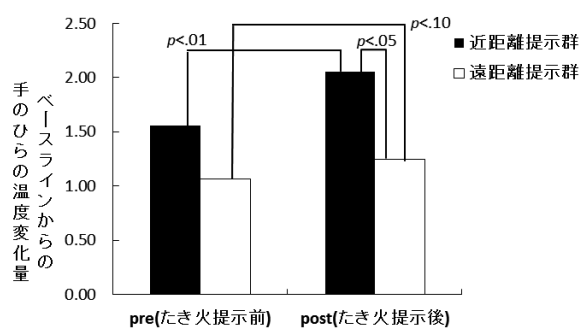

Figure 1. 各条件(たき火提示前後)に执ける手のひらの温度変化. 仮想刺激による温度感覚が所属欲求に及ぼす影響 所属欲求尺 度に関して合計得点を算出し，これを従属変数として，提 示条件間で $t$ 検定を行った。その結果, 近距離提示群 $(M$ $=3.37, S D=0.77)$ の方が, 遠距離提示群 $(M=2.92$, $S D=0.68)$ よりも高くなる傾向が示された $(t(30)=1.76$, $p<.10, d=.62)$ 。

\section{考察}

仮想現実環境上で提示された刺激に対しても, 実際に温 かさに関する身体反応が生じていた。かつ，その反応は提 示刺激との距離によって異なっていたことからも，あたか も現実世界と同じように仮想世界を体感していることが 推察される。加えて, 仮想の刺激からもたらされた温かさ に関する感覚は, 所属欲求の高まりという形で, 我々の認 知・思考にも影響を及ぼしている可能性も示された。 